\title{
Seasonal variations in zooplankton with reference to physico- chemical conditions in temple pond at Thiruvottiyur, Chennai
}

\author{
*J. Manju Bashini ${ }^{1}$, S. Pandiammal ${ }^{2}$ and P. Senthilkumaar \\ P.G. and Research Department of Zoology, Sir Theagaraya College, Chennai-21
}

\begin{abstract}
Seasonal dynamics of plankton diversity with reference to physico-chemical conditions in a fresh water pond was studied in temple pond at Thiruvottiyur, Chennai. Along with the physico-chemical parameters, water samples were also characterized for plankton community composition and density. The physico-chemical parameters also showed positive correlation with different zooplankton group. The water samples were analyzed for various physico-chemical factors. Totally 4 groups of zooplankton taxa were identified (Rotifera, Cladocerans, Ostracodans and Copepods). Zooplankton population density was maximum during summer (100 units/litre) and minimum (8.85 units/litre) during monsoon season. A total of 19 taxa were recorded (Rotifera 3, cladocerans 4, Ostracodans 6 and Copepods 6). Among the Rotifera, Branchionus and Keratella species; among the Cladocerans, Moina and Bosmina species; among the Ostracodans, Heterocypris and Physocypria species and among Copepods, Undinula and Pontellopsis species were abundant. The abundance of zooplankton in the pond follows a sequence as: Ostracodans $=$ Copepods > Cladocerans > Rotifera . Correlation between various physico-chemical parameters and zooplankton density was calculated. Some of the changes in zooplankton community structure were found associated with seasonal changes in temperature and nutrient content of water. Rise in DO and nutrient levels of nitrate, phosphate and silicate suggested favorable conditions for plankton growth. This study revealed that the presence of above mentioned species are considered to be biological indicator for eutrophication.
\end{abstract}

Keywords: Biodiversity, correlation, limnology, physico-chemical parameter, seasonal variations, zooplankton.

\section{Introduction}

Zooplankton organisms occupy a central position in the food webs of aquatic ecosystem. They do not only form an integral part of the lentic community but also contribute significantly, the biological productivity of the fresh water ecosystem [1]. [2] observed that Cladocerans and meroplanktonic larva reached peak abundance in saline water mass. [3] noticed that displacement volume were higher at those stations where swarms of hydromedusae and ctenophores occurred. A number of studies have been carried out on ecological conditions of fresh water bodies in various parts of India [4]. The requirements of water from protozoans to metazoans are a serious problem today because all water resources have reached to a point of crisis due to unplanned urbanization and industrialization. Water quantity assessment involves analysis of physico-chemical and biological parameters and reflects an abiotic and biotic status of the ecosystem [5]. The physico-chemical parameters are the major factors that control the dynamics and structure of the phytoplankton of aquatic ecosystem [6]. The importance of the Zooplankton is well recognized as these have vital part in food chain and play a key role in cycling of organic matter in an aquatic ecosystem [7]. Studies also been conducted on physico-chemical parameters and phytoplankton community [8], [9] and [10]. Identification of zooplankton species in food webs is essential part of managing aquatic bodies. Diversity of zooplankton can be used to indicate chronic water pollution problem. Zooplankton supports the economically important fish populations. The study of zooplanktonic composition abundance and seasonal variation is helpful in planning and successful fishery management. The physico - chemical factors and nutrient status of water played the most important role in governing the production of planktonic biomass [11]. Zooplankton plays an important role in food chain and food web of any type of ecosystem. It is major connecting link between producers and secondary consumers. The presence of zooplanktons is thus crucial to achieving high fish production during fish cultivation [12]. Aquatic environment plays an important role in growth and influencing physiology of fishes [13]. Several studies have been conducted on physico-chemical parameters in aspects of productivity status of confined water bodies [14].

The distribution depends on complex factors such as climatic factors, change in the environmental factors in fresh water ecosystem. It influences toxicity of various pollutants to fresh water organisms and sensitivity of these organisms to the toxicants. Zooplankton community constitutes an important component in the faunal composition of the water body. Therefore the present investigation attempts to study the Plankton species diversity in relation to water quality parameters. 


\subsection{Area of Sampling}

\section{Materials And Methods}

The present investigation was conducted in a temple pond situated at Thiruvottiyur, Chennai. (Fig. 1). The area of the pond are 1.0 ha and mean depth is $2 \mathrm{~m}$.

\subsection{Sampling Period}

The sampling was done in the first week of every month in early hours of the month (i.e, around 9.00 to 11.00 a.m)

\subsection{Water sample collection}

The sub surface water samples were collected from pond at four different seasons with the help of bucket. Care was taken to avoid any kind of spilling of water or air bubbling at the time of sample collection.

\subsection{Collection of zooplankton samples}

The plankton samples were collected from subsurface water by filtering 50 litres of water through plankton net made up of bolting silk no. 25 . The concentrated plankton samples were preserved by adding $5 \%$ formalin. The Sedgwick Rafter cell was used for quantitative estimation. Plankton was identified up to generic level following standard method [15].

\subsection{Qualitative study of zooplankton}

Preserved zooplankton samples were identified upto species level wise by observing them under a microscope. Systematic identification was done upto species level wherever possible by taking the help of [16] and [17] and several research publications.

\subsection{Quantitative study of zooplankton}

For quantitative zooplankton study, a sedge-wick rafter cell was used which is $50 \mathrm{~mm}$ long, $20 \mathrm{~mm}$ wide and $1 \mathrm{~mm}$ deep. The samples were transferred to the cell with a dropper. The air bubbles were avoided while transferring the sample to the cell. Before counting the zooplankton, it was ensured that all the organisms have settled down. Every sample was counted for the zooplankton at least five times and an average was taken for the samples of each month for one year, (i.e, during 2015-2016). The number of each species or genus was calculated by the following formula (Welch, 1948) and then total zooplanktonic forms were counted on monthly basis with the help of the following formula:

$$
\mathrm{N}(\operatorname{org} \mathrm{L}-1)=\frac{\mathrm{a} \times \mathrm{b}}{\mathrm{V}}
$$

$\mathrm{N}=$ Number of zooplankton per liter

$\mathrm{a}=$ The average number of zooplankton in all counts in a counting cell of $1 \mathrm{ml}$ capacity.

$\mathrm{b}=$ The volume of original concentrate in $\mathrm{ml}(30 \mathrm{ml})$

$\mathrm{V}=$ Volume of original water filtered (50 litres)

All the organisms were represented numerically as organisms per liter. The correlation between various physicochemical parameters and zooplankton groups was tested using the formula given below

$$
\begin{aligned}
& \text { Correlation coefficient }(\mathrm{r})=\frac{\mathrm{N} \Sigma \mathrm{nxy}-\Sigma \mathrm{x}-\Sigma \mathrm{y}}{\sqrt{\mathrm{N} \Sigma \mathrm{x} 2-(\Sigma \mathrm{x} 2)\{\mathrm{N} \Sigma \mathrm{Y} 2-(\Sigma \mathrm{Y}) 2\}}}
\end{aligned}
$$

\section{Results And Discussion}

\subsection{Species composition, Species diversity and Seasonal fluctuation of Zooplankton}

Data obtained from the study indicates that the total of 19 Zooplankton species was recorded in a pond (Table 1). The annual periodicity shows Ostracodans and Copepods equal dominancy and constitutes 33\%, Rotifera constitutes $15 \%$ and Cladocerans constitutes $19 \%$ (Fig. 2). To summarize Zooplankton abundance in the study area clearly depicted that Ostracodans and Copepoda distributed equally throughout the study period followed by Cladocerans and Rotifera (Ost=Cop $>$ Cla $>$ Rot). Zooplankton population density was maximum during summer (100 units/litre) and minimum (8.85 units/litre) during monsoon season. About more than 1500 species of Zooplankton have been described from the parts of the world [18] and [19]. All these groups contributed to zooplankton peak during post monsoon and pre monsoon.

\subsection{Correlation of Physico-chemical parameters with zooplankton}

The significant correlation was established between zooplankton density and physico-chemical parameters of the water samples at Thiruvottiyur temple pond was predicted in the Table 2 . Rotifera were highly significant showing positive correlations with temperature, free $\mathrm{Co}_{2}, \mathrm{pH}, \mathrm{Cl}_{2}$ and $\mathrm{N}_{2}$ whereas negative correlation with dissolved oxygen. Copepods showed highly positive correlations with free $\mathrm{Co}_{2}, \mathrm{pH}$ and $\mathrm{Cl}_{2}$ but negative correlations with dissolved oxygen. The similar observations were made by [20], [21] and [22]. Thus it may be concluded that the density of Zooplankton is dependent of different abiotic factors either directly. [23] 
discussed that temperature is one of the important and changing environmental factor in fresh waters of different geographical regions but also in the same water body during different time and seasons.

In autumn total zooplankton density and zooplankton variation are higher than other seasons, but these were the lowest in spring. Finally it is clear that environmental factors play an important role in zooplankton density in freshwater and physicochemical factors determine the population dynamics in this environment [24]. The zooplankton population of Anchar lake, a shallow lake, was found to be composed of Rotifera, Copepoda, Cladocerans and Ostracodans) of which rotifera were dominant in terms of species diversity followed by Cladocerans, Copepoda and Ostracoda. The quality and the quantity of the food available and the predation pressure due to the phytophagus species inhabiting the lake are also other vital factors controlling the growth and abundance of the group. The group Crustaceans which included Cladocerans, Copepods and Ostracodans also showed unimodal curve for their population though present during moderate temperature conditions. The crustacean group showed maximum numerical surge during warm periods and minimum during colder periods [25].

Zooplankton occurs distinctly in the study area and normally in rainy season there is a less population due to the dilution factors and its effects leads to less photosynthetic activity by primary producers. The population raises a bit higher level during winter season due to favourable environmental conditions and presence of excess of food in the form of bacteria and suspended detritus, but in summer where inflow is less to compare with other seasons resulted in stability of water body and availability of food is more due to decomposition of organic matter and the density of zooplankton might be high due to less predators [26]. Further contamination of water through domestic sewage was also been noticed which gradually reducing the productivity status of the ecosystem. Proper biological and chemical treatments of domestic sewage need to be done before discharge to the system for long run sustainable of the resources [27].

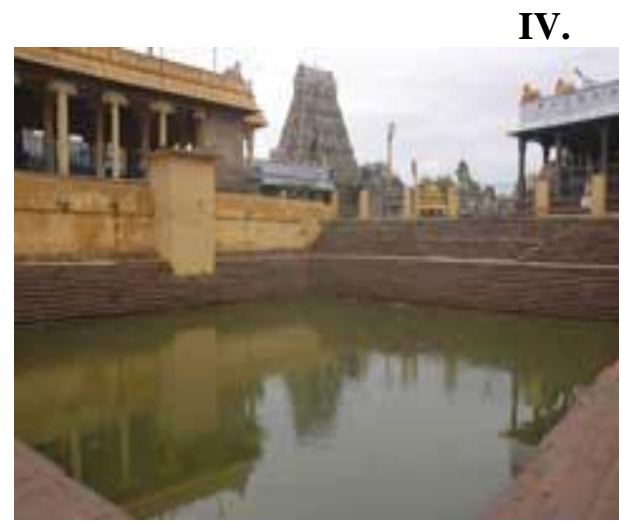

Figure 1: Temple Pond, Thiruvottiyur
Figures And Tables

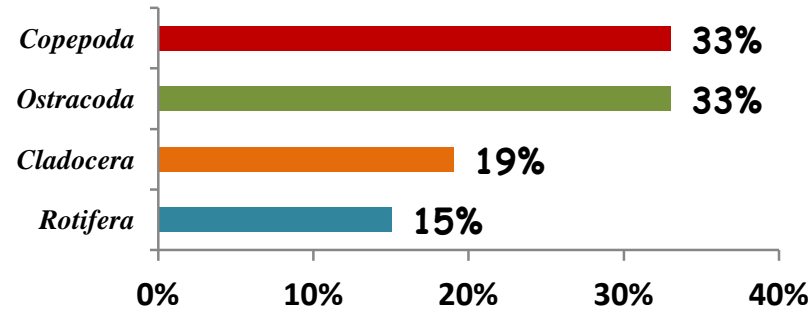

Figure 2: Showing the percentage of seasonal distribution of zooplankton in the study area

\begin{tabular}{|c|c|c|c|c|}
\hline Plankton Species & Summer & Premonsoon & Monsoon & Postmonsoon \\
\hline \begin{tabular}{ll} 
& \multicolumn{1}{c}{ Rotifera: } \\
1. & Branchinous calafertus \\
2. & Branchinous calyciflorus \\
3. & Keratella tropica
\end{tabular} & $\begin{array}{l}+ \\
+ \\
+\end{array}$ & $\begin{array}{l}+ \\
+ \\
-\end{array}$ & $\begin{array}{l}+ \\
+ \\
+\end{array}$ & $\begin{array}{l}- \\
+ \\
+\end{array}$ \\
\hline \begin{tabular}{ll} 
& \multicolumn{1}{c}{ Copepoda: } \\
1. & I. Calonoid \\
2. & Pontinula vulgaris \\
3. & Pontellopsis scotti \\
4. & Temora discaudata \\
& \\
& II. Cyclopids \\
1. & Mesocyclops aspericornis \\
2. & Thermocyclops hyatinus
\end{tabular} & $\begin{array}{l}+ \\
+ \\
+ \\
-\end{array}$ & $\begin{array}{l}+ \\
+ \\
+ \\
+\end{array}$ & $\begin{array}{l}+ \\
+ \\
+ \\
-\end{array}$ & $\begin{array}{l}+ \\
+ \\
- \\
+\end{array}$ \\
\hline $\begin{array}{ll} & \text { Cladocera: } \\
\text { 1. } & \text { Moina micruna } \\
\text { 2. } & \text { Moina macroiopa } \\
\text { 3. } & \text { Kurzia longirostris } \\
\text { 4. } & \text { Bosmina coregoni }\end{array}$ & $\begin{array}{l}+ \\
+ \\
+ \\
+\end{array}$ & $\begin{array}{l}+ \\
+ \\
+ \\
+\end{array}$ & $\begin{array}{l}+ \\
+ \\
+ \\
+\end{array}$ & $\begin{array}{l}- \\
+ \\
- \\
+\end{array}$ \\
\hline
\end{tabular}




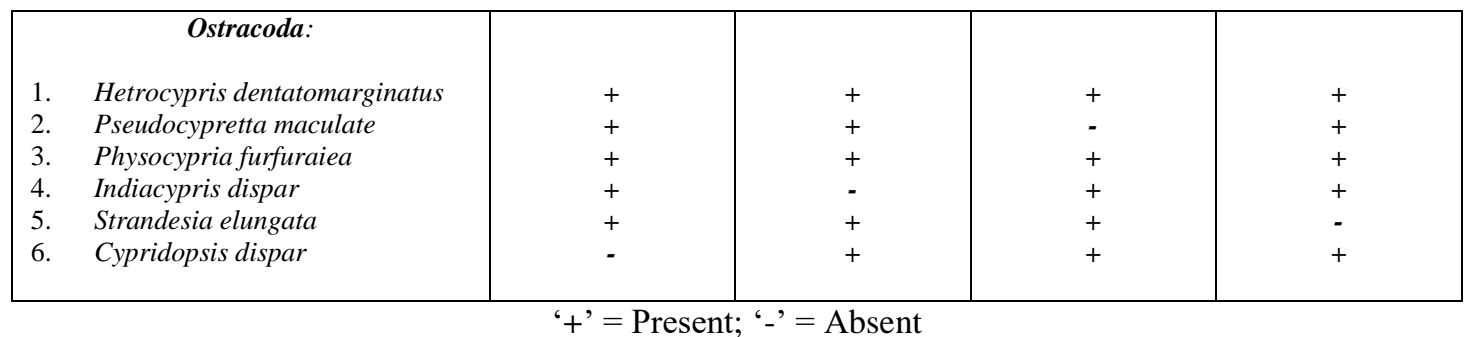

Table 1: Distribution of zooplanktons in Thiruvottiyur temple pond in various seasons

\begin{tabular}{|l|c|c|c|c|}
\hline \multicolumn{1}{|c|}{ Physico-chemical Parameter } & Rotifera & Cladocera & Copepoda & Ostracoda \\
\hline & & & & \\
Temperature $\left({ }^{\circ} \mathrm{c}\right)$ & \pm 0.26 & \pm 0.19 & \pm 0.26 & \pm 0.24 .23 \\
Turbidity (NTU) & \pm 0.11 & \pm 1.23 & \pm 0.72 & \pm 0.94 \\
Transparency $(\mathrm{cm})$ & \pm 1.45 & \pm 1.32 & - & - \\
pH & \pm 1.34 & \pm 1.45 & \pm 1.74 & \pm 1.65 \\
D.O (mg/l) & \pm 0.12 & \pm 0.13 & \pm 0.14 & \pm 0.14 \\
Free co2(mg/l) & \pm 0.06 & \pm 0.07 & \pm 0.07 & \pm 0.07 \\
Alkalinity (mg/l) & \pm 2.65 & \pm 2.78 & \pm 3.54 & \pm 3.54 \\
Hardness (mg/l) & \pm 1.7 & \pm 1.9 & \pm 1.05 & \pm 1.9 \\
Phosphate (mg/l) & \pm 0.01 & \pm 0.01 & \pm 0.012 & \pm 0.016 \\
Nitrate (mg/l) & \pm 0.064 & \pm 0.054 & \pm 0.059 & \pm 0.071 \\
Silicate (mg/l) & \pm 0.54 & \pm 0.45 & \pm 0.44 & \pm 0.052 \\
& & & & \\
\hline
\end{tabular}

Table 2: Levels of significance of physico-chemical variables of zooplankton

\section{Conclusion}

The abundance of zooplankton was influenced by many physico-chemical factors and also depends upon the interaction among biological factors. Most of them are also indicative of the potential problem likely to affect on the aquatic ecosystems. The magnitude of the threat to and loss of biodiversity is an indicator of the extent to which current practices are unsustainable. A mixture of strategies will be essential to preserve fresh water biodiversity in the long term it must include reserves that protect key biodiversity rich water bodies and their catchments as well as species are habit centered plants that reconcile the protection of biodiversity and societal use of water resources in the context of human modifies ecosystems. This study revealed that the presence of above mentioned species are considered to be biological indicators for eutrophication.

\section{References}

[1]. Wetzell, R. G. (2001): Limnology: Lake and river Ecosystem, 3rd ed. Academic Press. ISBN -12-744760-1.

[2]. Patil, J.S. (2003) Diatoms in benthic and pelagic environment. In: Studies on ecology of diatoms. Ph.D. Thesis, University of Goa, India, pp. 47-50.

[3]. Mishra, N.K. (2005) Limnological study and plankton, Interim fish culture of Gurma Bundh Rewa District (M.P.). Thesis submitted A.P.S. University (M.P).

[4]. Smitha, P.G., K. Byrappa and S.N. Ramaswamy. (2007) Physico-chemical characteristics of water samples of bantwal Taluk, South-estern Karnataka, India. J. Environ. Biol., 28: 591-595.

[5]. Mulani, S.K., M.B. Mule and S.U. Patil. (2009) Studies on water quality and zooplankton community of the Panchganga river in Kolhapur city. J. Environ. Biol., 30: 455-459.

[6]. Hulyal, S.B. and B.B. Kaliwal. (2009) Dynamics of phytoplankton in relation to physico-chemical factors of Almatti reservoir of Bijapur district, Karnataka State. Environmental Monitoring and Assessment., 53: 45-59.

[7]. Sharma, R.C., N. Singh and A. Chauhan. (2016) The influence of physico-chemical parameters on phytoplankton distribution in a head water stream of Garhwal Himalayas: A case study. Egyptian Journal of Aquatic Research., 42: 11-21.

[8]. Hassan, M.A., M.K. Bhandhopadhyay., B.C. Jha., A.P. Sharma and B.K. Biswas. (2011) Plankton and fish productivity pattern in two environmentally different oxbow lakes in West Bengal. Journal of Inland Fisheries Sciences., 43(1): 70-76.

[9]. Nowrouzi, S. and H. Valavi. (2011) Effects of environmental factors on phytoplankton abundance and diversity in Kaftar Lake. Journal of Fisheries \& Aquatic Science., 6(2): 130-140.

[10]. Ogbuagu, D.H., A.A. Ayoade and N.B. Chukwuocha. (2011) Spatial dynamics in physic-chemistry and bacterio and myco-plankton assemblages of Imo River in a Niger Delta community in Nigeria. African Journal of Microbiology Research., 5(8): 872-887.

[11]. Ravindra Kumar Singh, Manoj kumar pandey, Rakhi Kumari, Pramod Ranjan (2012). Study on the Diversity and Seasonal Variation of Zooplankton in Mahendra Nath Pond, Siwan, Bihar. International Journal of Pharmaceutical \& Biological Archives., 3(4): 867-870.

[12]. Agrawal, R.K., Sanjay Thiske and Sunil Mondal. (2014) Diversity and Seasonal Fluctuation of Zooplankton in Fresh Water Reservoir Mongra Bairaj Rajnandgaon District, CG, India. Research Journal of Animal, Veterinary and Fishery Sciences., 2(8): 1-4.

[13]. Reddy, G.S., D. Balakrishna and T.R. Reddy. (2015) A Study of Physico-Chemical Parameters and Fish Diversity of Nizam Sagar Dam, Nizamabad, Telangana. International Journal of Fisheries and Aquatic Studies., 3(2): 248-254.

[14]. Shailendra Sharma, Anis Siddique, Karam Singh, Meenakshi Chouhan, Amrita Vyas, C.M.Solnki, Dhavni Sharma, Smitha Nair and Taniya Sengupta. (2010) Population Dynamics and Seasonal Abundance of Zooplankton Community in Narmada River (India). Researcher., 2(9): 1-9. 
[15]. APHA, AWWA, WEF (2012). Standard Methods for examination of water and wastewater. 22nd ed. Washington: American Public Health Association. pp. 1360.

[16]. APHA. (1998) Standard Methods for Examination of water and Waste Water. 20th Edition. American Public Health Association, Washington D.C.

[17]. Edmondson, W.T. (1992) Freshwater biology. Second Eds., John Wiley \& Sons.Inc., New York, p. 1248

[18]. Mulani, S.K., M.B. Mule and S.U. Patil. (2009) Studies on water quality and zooplankton community of the Panchganga river in Kolhapur city. J. Environ. Biol., 30: 455-459.

[19]. Nogueira, M.G. (2001) Zooplankton composition dominance and abundance as indicators environmental compartmentalization in Jurumirim reservoir (Paranapanema river), Sao Paulo, Brazil. Hydrobiologia., 455: 1-18.

[20]. Ismail, Q. (1997) Seasonal variation of Rotifera and certain physico-chemical factors of pipliya pala pala Tal, Indore. Proc.Acad. Enviro.Bios., 6(2): 139-144.

[21]. Prakash, S. (2000) Seasonal dynamics of plankton in a fresh water body at Balrampur. Geobios., 28(1): 36-39.

[22]. Prakash, S. and R.R. Srivastava. (2001) Hydrological parameters on population of Cladocera and Copepods of Motisagar Tal, Balrampur, U.P. Anta Ecol., 23(1).

[23]. Sharma, M. S., F. Liyaquat., D. Barber and N. Chisty. (2000). Poll. Res., 19(1) : 147-157

[24]. Shayestehfar, A., M. Noori and F. Shirazi. (2010) Environmental factor effects on the seasonally changes of zooplankton density in Parishan Lake (Khajoo Spring site), Iran. Asian J. Exp. Biol. Sci., 1(4): 840- 844.

[25]. Ahangar, I. A., D.N. Saksena., M.F.Mir., M.A. Ahangar. (2012) Crustacean community in Anchar lake, Kashmir. Bull. Environ. Pharmacol. Life Sci., 1: 18-21.

[26]. Shivashankar, P. and G.V. Venkataramana. (2013) Zooplankton Diversity and their Seasonal Variations of Bhadra Reservoir, Karnataka, India. International Research Journal of Environment Sciences., 2(5): 87-91.

[27]. Rishikanta Singh, N., S.K. Das., Sanjeev Kumar., Dibakar Bhakta., S. Behera., T.S. Nagesh and Anandamoy Mondal. (2017) Limnology and productivity status in wetlands (Beels) of 24- South Parganas district, West Bengal. Journal of Entomology and Zoology Studies., 5(2): 664-668.

J. Manju Bashini. " Seasonal variations in zooplankton with reference to physico-chemical conditions in temple pond at Thiruvottiyur, Chennai." IOSR Journal of Environmental Science, Toxicology and Food Technology (IOSR-JESTFT) 11.7 (2017): 01-05. 